\title{
Intermittent protein restriction improves glucose homeostasis and restores damaged islet beta cells in diabetic mice
}

\section{Siying Wei}

Chinese Academy of Sciences

Chenchen Li

Chinese Academy of Sciences

\section{Xuemei Luo}

Chinese Academy of Sciences

\section{Lanzexin Yang}

Chinese Academy of Sciences

\section{Long Yu}

Chinese Academy of Sciences

\section{Qintao Wang}

Zhejiang University

\section{Zhuo-Xian Meng}

Zhejiang University

\section{Tao Wang}

Chinese Academy of Sciences

Yan Chen ( $\sim$ ychen3@sibs.ac.cn)

Chinese Academy of Sciences https://orcid.org/0000-0002-6630-0693

\section{Keywords:}

Posted Date: December 10th, 2020

DOl: https://doi.org/10.21203/rs.3.rs-119927/v1

License: (c) (i) This work is licensed under a Creative Commons Attribution 4.0 International License. Read Full License 


\section{Abstract}

The authors have requested that this preprint be removed from Research Square. 